\title{
PEMBERDAYAAN ANAK DAN REMAJA PEREMPUAN MELALUI PEMBELAJARAN BAHASA INGGRIS DI DESA GOLONG, KEC. NARMADA MENGGUNAKAN PENDEKATAN COLLABORATIVE LEARNING
}

\author{
Puspita Dewi' , Nurul Hidayah², Isra Dewi Kuntary Ibrahim³, Baiq Fitria Rahmiati4 ${ }^{4}$ Sirojul Hadi5 \\ 1,2,3,4,5 Universitas Bumigora, Mataram, Indonesia \\ *Penulis Koresponsensi, email: puspitadewi@universitasbumigora.ac.id
}

Received:26/01/2021

Revised:28/01/2021

Accepted:31/01/2021

\begin{abstract}
Various issues in villages become one of the obligations of academicians or lecturers to solve the problems faced by society. Golong is a village that has the uniqueness and opportunity to be a developed village both for natural resources and human resources. Even though the society has low income but the spirit of the society is high. Therefore, community service team initiates to guide in learning English for children and women teenagers in Golong, Narmada, and West Lombok. Collaborative learning is one of the methods used in this community service activity because it involves and provides plenty opportunity to the learners for sharing and discussing of the materials and to solve the matters. Consequently, by applying the collaborative learning approach, the learners are expected to be more active in learning and cooperating so that their habits of learning and collaboration to be implemented by the learners in workplaces. The community service results show that guidance and empowerment in learning English have a positive impact and have a good response from the learners and community. The empowerment has a pivotal role in encouraging the learners' motivation and improves the learners' achievements. The community service activity is expected to be able to be sustainable and become one of cooperation between institutions and villages so that the institution contributes to shape the society to be smart, wise, and prosperous.
\end{abstract}

Keywords: collaborative learning, english, village, empowerment

\begin{abstract}
Abstrak. Berbagai permasalahan yang ada di desa menjadi salah satu kewajiban akademisi atau dosen untuk membantu menyelesaikan masalah yang dihadapi masyarakat termasuk masalah pendidikan. Desa Golong merupakan desa yang memiliki khas dan peluang yang besar untuk dikembangkan baik dari segi Sumber Daya Alam dan Sumber Daya Manusia. Walaupun pendapatan masyarakat masih dikategorikan belum terlalu tinggi akan tetapi semangat belajar masyarakat di desa tersebut tinggi. Oleh sebab itu, tim Pengabdian kepada Masyarakat (PkM) Universitas Bumigora berinisiasi untuk memberikan pendampingan belajar bahasa Inggris untuk anak-anak dan remaja perempuan yang ada di desa Golong, Kecamatan Narmada, Kabupaten Lombok Barat. Collaborative learning merupakan salah satu pendekatan yang digunakan dalam kegiatan PkM ini karena pendekatan ini melibatkan dan memberikan banyak kesempatan kepada pembelajar untuk berbagi dan berdiskusi tentang materi yang dipelajari serta dapat bertukar pikiran untuk menyelesaikan masalah. Akibatnya, dengan menggunakan pendekatan collaborative learning, pembelajar diharapkan lebih aktif dalam belajar dan bekerjasama sehingga budaya belajar dan kerjasama ini dapat diimplementasikan oleh pembelajar sampai di dunia kerja. Hasil PkM menunjukkan bahwa Pembinaan dan pendampingan belajar bahasa Inggris memiliki efek dan respon yang positif baik dari pembelajar maupun masyarakat setempat. Hasil pembinaan memiliki peran penting dalam mendorong motivasi belajar dan hasil belajar anak-anak dan remaja setempat. Kegiatan PkM ini diharapkan mampu menjadi kegiatan yang berkelanjutan dan dapat menjadi salah satu bentuk mitra yang baik antara institusi dan desa sehingga institusi dapat berkontribusi dalam membentuk masyarakat yang lebih cerdas, bijak, dan sejahtera.
\end{abstract}

Kata Kunci: collaborative learning, bahasa inggris, desa, pendampingan

How to Cite: Dewi, P., Hidayah, N., Ibrahim, I. D. K., Rahmiati, B. F., \& Hadi, S. (2021). PEMBERDAYAAN ANAK DAN REMAJA PEREMPUAN MELALUI PEMBELAJARAN BAHASA INGGRIS DI DESA GOLONG, KEC. NARMADA MENGGUNAKAN PENDEKATAN COLLABORATIVE LEARNING. Mitra Mahajana: Jurnal Pengabdian Masyarakat,2(1),1-6. doi: https://doi.org/10.37478/mahajana.v2i1.809

\section{PENDAHULUAN}

Pengabdian ini merupakan salah satu pengabdian yang dilakukan di Desa Golong, Kec.Narmada, Kabupaten Lombok Barat. Salah satu tujuan dari Pengabdian kepada Masyarakat (PkM) ini adalah meningkatkan mutu daya saing Sumber Daya Manusia (SDM) terutama anakanak dan remaja di desa binaan. Di desa ini sebagian besar mata pencaharian pokok masyarakatnya adalah petani dan buruh tani. Namun, rata-rata anak-anak dan remaja di sana 
mengenyam pendidikan yang baik karena motivasi orang tua yang tinggi untuk menyekolahkan anak-anaknya.

Ada berbagai permasalahan yang dihadapi oleh masyarakat desa Golong diantaranya pendapatan masyarakat masih rendah sehingga ini juga berdampak terhadap kekurangmampuan anak-anak di desa tersebut untuk mengikuti kursus atau belajar tambahan di luar seperti mengikuti kursus bahasa Inggris. Antusiasme anak-anak dan remaja desa Golong mulai muncul dan termasuk dalam kategori cukup tinggi untuk mempelajari bahasa Inggris karena salah satu pemuda desa tersebut sudah mendapatkan beasiswa ke Luar Negeri (Belanda) sehingga para orang tua memiliki semangat yang tinggi untuk mendorong anakanaknya belajar bahasa Inggris. Lebih-lebih Bahasa Inggris tidak diajarkan di Sekolah di desa Golong. Atas berbagai permasalahan tersebut, dibutuhkan penguatan kepada masyarakat setempat berupa soft skill yaitu pembinaan dan pelatihan Bahasa asing termasuk Bahasa Inggris kepada generasi muda yaitu anak-anak dan remaja di desa tersebut.

Bahasa asing (Bahasa Inggris) menjadi salah satu bahasa dunia yang dijadikan sebagai salah satu alat komunikasi antar manusia di seluruh penjuru dunia. Perdagangan bebas dan wisata yang melambung tinggi tidak bisa terlepas dari bahasa Inggris sehingga diperlukan pelatihan, pendampingan dan pengajaran Bahasa Inggris untuk masyarakat setempat terutama anak-anak dan remaja. Bahasa Inggris menjadi salah satu skill yang harus dikuasai oleh masyarakat setempat terutama generasi millennial supaya dapat mengelola dan mengembangkan perekonomian daerah setempat baik melalui perdagangan, pendidikan, pertanian, atau segala sektor yang ada yang bisa dikembangkan. Dewi (2017) menyebutkan bahwa bahasa Inggris sebagai salah satu bahasa dunia sangat dibutuhkan dipelajari mendapatkan pekerjaan dan masa depan yang lebih baik. Untuk mencapai tujuan tersebut, tim dosen Universitas Bumigora berinisiatif melakukan Pengabdian kepada Masyarakat dengan memberikan pendampingan dan pembinaan bahasa Inggris untuk anak-anak dan remaja di desa Golong supaya bisa dimanfaatkan dan digunakan dalam peningkatan kualitas hidup masyarakat setempat. Dengan cara memberikan pelatihan bahasa diharapkan anak-anak dan pemuda mampu mengerti, memahami, dan mengimplementasikan bahasa Inggris sehingga dapat memberikan kontribusi yang positif terhadap kehidupan keluarga dan kehidupan mereka sendiri kedepannya. Hal ini juga dapat menjadi bagian dari membantu pemerintah daerah dan nasional dalam mengentaskan buta huruf, meningkatkan kesadaran akan pendidikan, dan mengentaskan kemiskinan sehingga taraf hidup masyarakat Indonesia umumnya dan Lombok khususnya lebih tinggi dan lebih baik.

Adapun pendekatan atau metode yang digunakan dalam PkM ini adalah collaborative learning yaitu memfokuskan pada kegiatan kolaborasi antara tutor dengan pembelajar dan pembelajar dengan pembelajar lainnya. Pendekatan Pembelajaran Kolaborasi sudah banyak diteliti dan dimplementasikan dalam pembelajaran; Mbirimi-Hungwe \& McCabe (2020) menuliskan bahwa collaborative learning memiliki peran penting dalam pendidikan di pendidikan Tinggi sejak akhir tahun 1980an sehingga banyak penelitian yang memiliki topic tersebut. Engwall \& Lopes (2020) menyatakan bahwa kolaborasi dengan teman sejawat atau patner dapat meningkatkan daya latihan. Karena otonomi dari pembelajaran kolaborasi adalah pembelajar memiliki otonom dalam mengadopsi strategi komunikasi yang tepat untuk terlibat dalam kelompok (Su \& Zou, 2020). Vahed \& Rodriguez (2020) juga mendukung bahwa collaborative learning dengan rekan global (internasional) atau istilah The Collaborative Online International Learning (COIL) dapat meningkatkan kesadaran antar budaya, pengetahuan yang lebih spesifik, keterampilan berkomunikasi serta bekerjasama. Selanjutnya Chen (2020) menyebutkan bahwa proses collaborative learning melibatkan usaha kolektif atau bersamasama.

\section{METODE PELAKSANAAN}

Pengabdian kepada Masyarakat (PkM) ini dilaksanakan di Desa Golong, kecamatan Narmada, Kabupaten Lombok Tengah dengan menggunakan pendekatan collaborative learning 
dengan memberikan kesempatan berbicara lebih banyak kepada pembelajar dan mendorong mereka berbicara dengan membangun komunikasi dengan patner mereka. Metode ini lebih difokuskan pada kegiatan kolaborasi antar satu pembelajar dengan pembelajar yang lain untuk memecahkan masalah, saling memotivasi, dan saling mengoreksi serta memberikan saran.

Metode collaborative learning dalam kegiatan PkM ini menekankan pada proses exposure yaitu memberikan kesempatan yang besar kepada para pembelajar untuk berbicara dan latihan berbahasa Inggris. Oleh sebab itu, metode ini lebih cocok digunakan dalam pembelajaran speaking dibandingkan keterampilan lainnya seperti grammar, writing dan reading. Pendampingan dilakukan selama 6 kali (sekali dalam seminggu) dengan jumlah peserta sebanyak 20 pembelajaran baik anak-anak maupun remaja perempuan. Dalam proses belajar mengajar, tutor memilih aktifitas dengan konsep belajar dan bermain. Durasi waktu belajar yaitu sekitar sampai 2 (dua) jam. Belajar di dalam ruang sekitar 30 menit dan sisanya belajar di ruang alam (di luar ruang).

Dalam proses belajar mengajar, tutor menyelipkan nilai-nilai keadilan gender, kepemimpinan, dan kerjasama melalui permainan dan instruksi. Ini bertujuan untuk meningkatkan kesadaran anak-anak dan remaja tentang pentingnya menegakkan nilai keadilan gender dan nilai-nilai kebaikan lainnya sejak dini. Pendekatan collaborative learning mendorong dan mengajak pembelajar untuk kerjasama sesame rekannya sehingga harapannya nanti di dunia kerja dapat beradaptasi lebih cepat dan lebih baik. Dalam hal ini, dosen Bahasa Inggris, Gizi, Manajemen, dan Teknologi Informasi berkolaborasi dalam proses kegiatan Pengabdian kepada Masyarakat di desa Golong.

\section{HASIL DAN PEMBAHASAN}

Hasil PkM menunjukkan bahwa kemampuan Bahasa Inggris anak-anak dan remaja di desa Golong meningkat walaupun belum signifikan karena pertemuan belum terlalu intens dan lama. Ini dibuktikan dari kemampuan mereka dalam mengekspresikan dan menggunakan Bahasa Inggris seperti memperkenalkan diri, angka, menyebutkan nama buah-buahan, nama binatang, nama hari, nama-nama benda di sekitar dan dalam rumah, serta nama-nama benda di sekitar mereka. Kegiatan Pengabdian pada Masyarakat ini dilakukan sekitar 2 bulan dari bulan Oktober sampai dengan November dengan 6 kali pertemuan di desa Golong, kecamatan Narmada, kabupaten Lombok Barat. Kegiatan ini dilakukan pada hari ahad sore dari jam 16.0018.00 WITA. Beberapa topik yang diajarkan disetiap pertemuannya yaitu introduction, fruits, numbers, animals, house, nouns around us.

Pertama, pembelajar diajarkan tentang introduction yaitu bagaimana memperkenalkan diri dalam bahasa Inggris. Tutor memberikan materi bagaimana saling menyapa dalam bahasa Inggris dan memperkenalkan diri dan bermain peran seperti bermain peran dalam drama karena teknik seperti ini akan membangun tingkat kepercayaan diri pembelajar untuk berpikir dan berbicara lantang (Dewi et al., 2020). Metode Question and Answer (Q\&A) digunakan untuk menstimulus pembelajar untuk berkomunikasi satu dengan yang lainnya. Setelah itu, tutor meminta pembelajar untuk latihan secara berpasang-pasangan. Kemudian tentang numbers, pada pertemuan ini anak-anak diajarkan tentang angka dalam bahasa Inggris. Tutor menuliskan angka di papan kemudian menuliskan huruf dan drill pembelajara satu persatu dengan meniru apa yang tutor katakan. Fransiska (2016) menyatakan bahwa teknik drilling dapat meningkatkan penguasaan kosa kata bagi anak-anak dan remaja atau anak-anak SMP.

Selanjutnya anak-anak belajar tentang fruits. Media gambar digunakan dalam pertemuan kali ini. Tutor membawa gambar yang berisi beberapa jenis buah-buahan seperti apple, mango, orange, dan lainnya. Tutor akan menyebutkan bahasa Inggris dari buah-buahan tersebut satu persatu dan diulang beberapa kali. Setelah itu, satu pembelajar akan menunjuk satu buah kemudian pembelajar lainnya akan menebak bahasa Inggris dari buah tersebut.

Pertemuan selanjutnya tentang A House. Anak-anak diajarkan menggunakan media sticky note (small cards). Setiap kartu terdiri dari satu kata seperti windows, wall, chair, roof, 
door,dan lainnya. Pembelajar diberikan input terkait dengan semua benda yang berkaitan dengan rumah kemudian dilatih. Setelah itu, pembelajar diberikan sticky notes tersebut supaya ditempelkan sesuai dengan apa yang mereka dengar. Tutor akan mengatakan satu kata, misalnya window kemudian pembelajar yang memegang kata itu harus menempelkannya langsung di benda tersebut.

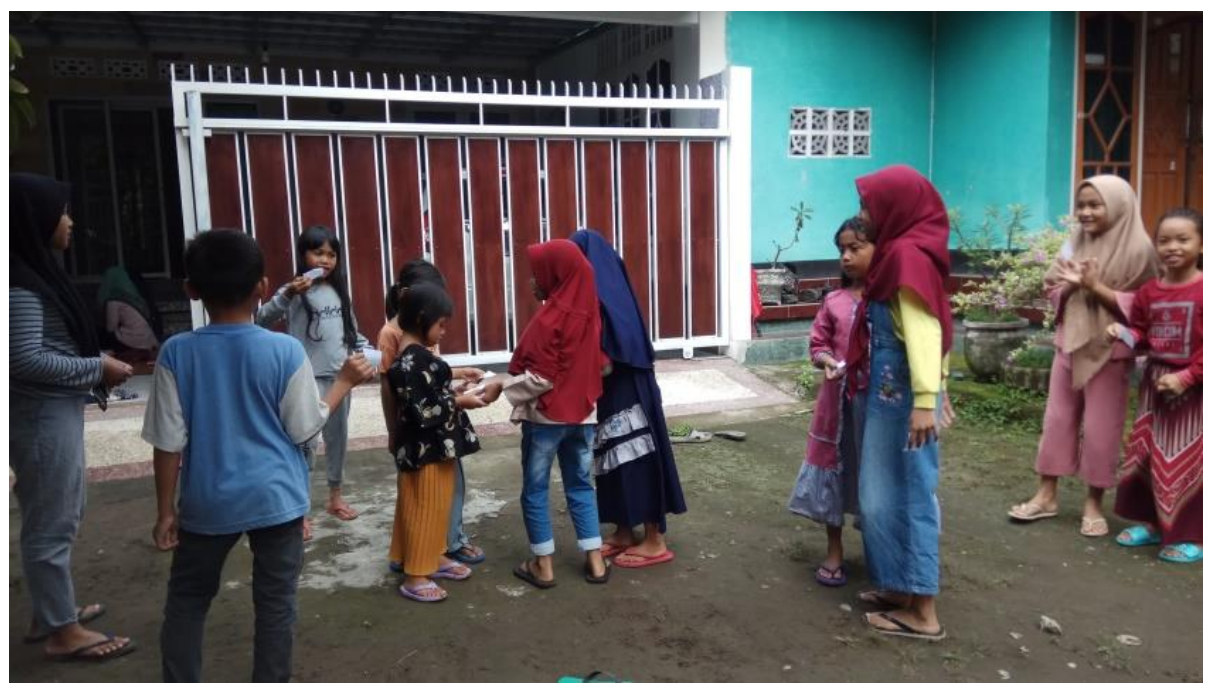

Gambar 1: Belajar di luar ruang

Pertemuan terakhir membahas tentang nouns around us. Siswa diajarkan Bahasa Inggris terkait benda-benda yang ada disekitar mereka, contohnya, batu, pohon, kayu, bambu, tanah, bunga, rumah, papan pengumuman, jendela, pintu, lantai, atap, dan lainnya. Siswa diajarkan tentang benda-benda tersebut, kemudian mereka akan menghafalkannya. Setelah itu, mereka akan praktik menyebutkan (drill) masing-masing benda tersebut dalam Bahasa Inggris. Dalam implementasi praktiknya, pengajar menunjuk beberapa benda yang ada di sekitar mereka kemudian siswa akan menyebutkannya dalam Bahasa Inggris benda yang ditunjuk atau pengajar yang menyebutkan benda-benda tersebut kemudian mereka yang menunjukkan benda-benda yang disebutkan.

Dalam proses belajar mengajar menggunakan pendekatan collaborative learning dengan membuat kegiatan yang melibatkan banyak pembelajar dengan tujuan pembelajar dapat berkolaborasi dalam memecahkann masah, memotivasi, dan saling memberikan feedback satu pembelajar dengan pembelajar lainnya. Maharani dkk. (2020) menyebutkan bahwa collaborative learning merupakan pendekatan yang menekankan pada kegiatan dengan mendorong anak-anak untuk bertanya, mengobservasi, dan berdiskusi sehingga mereka dapat belajr mandiri dan dapat memecahkan masalah secara bersama-sama.
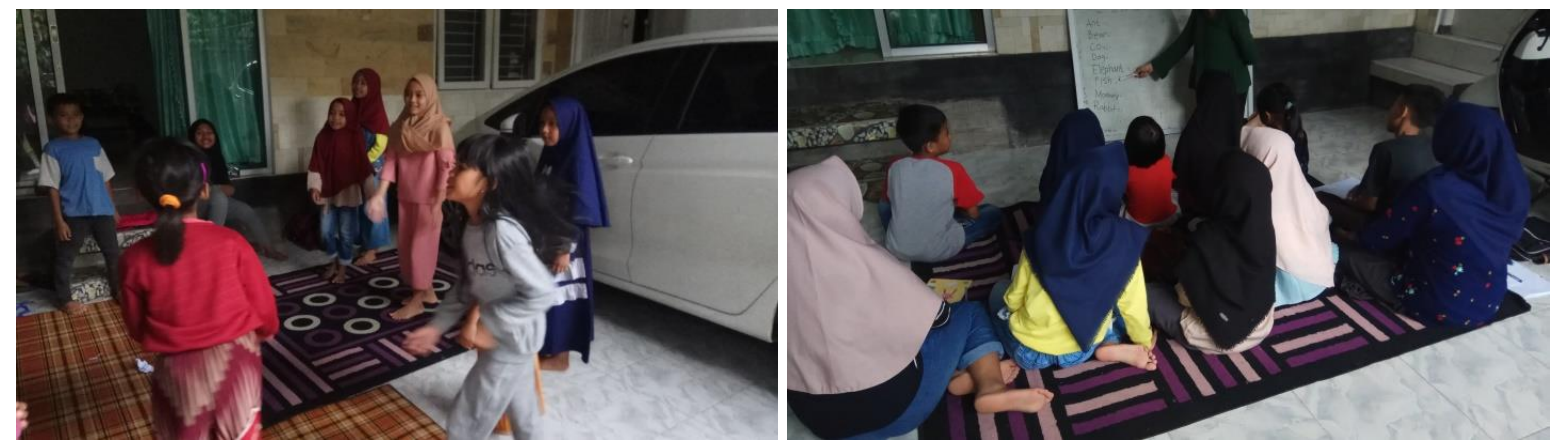

Gambar 2: Belajar sambil bermain games 
Collaborative learning juga ini dikombinasikan dengan permainan dan dikemas dengan menarik berdasarkan materi yang diajarkan hari itu. Hal ini berdampak positif terhadap motivasi dan kemampuan pembelajar dalam memahami materi dan lebih percaya diri dalam menggunakan bahasa Inggris. Btudermann (2015); Fenton-O'Creevy \& Carien van Mourik (2016) dan Grigoryan (2020) menjelaskan bahwa collaborative learning melalui games dapat menstimulus persepsi pembelajar (Bahari, 2020) supaya berpikir lebih kritis dan lebih aktif berkomunikasi dalam bahasa Inggris. Melalui collaborative learning anak-anak atau pembelajar mampu bekerja bersama-sama sehingga dapat menumbuhkan dan meningkatkan pemahaman pembelajar tentang materi yang diajarkan (Manegre et al., 2020).

Kegiatan dirancang sesuai dengan minat dan ketertarikan pembelajar, misalnya mencari game yang milenial dan menyenangkan sehingga ini akan membuat mereka tidak bosan dan senang mengikuti pembelajaran sampai akhir. Troussas et al. (2020) merekomendasikan kegiatan kolaborasi diterapkan pada pembelajaran dengan mempertimbangkan kebutuhan dan pilihan pembelajar sebagai upaya untuk meningkatkan daya tarik mereka untuk terlibat dalam kegiatan tersebut. Sepadan dengan pendapat Bernard, Rubalcava, \& St-Pierre (2000) dan So \& Brush (2008) dalam (Kuo \& Kuo, 2020) menuliskan bahwa collaborative learning telah dipertimbangkan menjadi salah satu metode yang paling efektif dari berbagai jenis setting pembelajaran, baik pembelajaran konvensional maupun pembelajaran yang dicampur (hybrid) sehingga ini dapat menjadi salah satu acuan yang dapat digunakan oleh pengajar untuk diimplementasikan di dalam kelas.

\section{SIMPULAN DAN TINDAK LANJUT}

Berbagai permasalahan di masyarakat sudah menjadi bagian dari tugas dosen berkontribusi dalam mencari solusinya. Desa Golong menjadi salah satu target desa yang dibina oleh TIM PkM Universitas Bumigora karena desa tersebut memiliki keunikan dan kekhasan tertentu, pendapatan orang tua di desa tersebut masih rendah akan tetapi motivasi belajar anak-anak dan remaja di desa tersebut tinggi. Memberikan pendampingan belajar bahasa Inggris menjadi salah satu solusi yang tepat untuk menumbuhkan dan mendorong anak-anak untuk tetap belajar. Pendekatan collaborative learning dijadikan sebagai salah satu metode yang tepat dalam pelaksanaan PkM ini dikemas dengan konsep bermain. Hasil PkM memberikan dampak positif terhadap keterampilan anak-anak dan remaja di desa tersebut. Kegiatan ini mendapatkan respon yang baik dari peserta dan orang tua serta masyarakat setempat. Kegiatan ini diharapakan tetap terus berjalan dan berlanjut sebagai upaya membantu masyarakat setempat.

\section{DAFTAR PUSTAKA}

Bahari, A. (2020). Game-based collaborative vocabulary learning in blended and distance L2 learning. Open Learning, 00(00), 1-22. https://doi.org/10.1080/02680513.2020.1814229

Chen, L. (2020). A historical review of professional learning communities in China (1949-2019): some implications for collaborative teacher professional development. Asia Pacific Journal of Education, 40(3), 373-385. https://doi.org/10.1080/02188791.2020.1717439

Dewi, P. (2017). Teaching English for Young Learners Through ICTs. Humanitatis: Journal on Language and Literature, 6(1), 149-156. https://doi.org/10.24176/03.3201.18

Dewi, P., Yuliatin, R. R., Hastuti, H., \& Muhid, A. (2020). Drama in Enhancing Motivation of NonEnglish Department Students: Computer Science Students. METATHESIS: JOURNAL OF ENGLISH LANGUAGE LITERATURE AND TEACHING, 4(2), 118-127. https://doi.org/10.31002/metathesis.v4i2.2279

Engwall, O., \& Lopes, J. (2020). Interaction and collaboration in robot-assisted language learning for adults. Computer Assisted Language Learning, 0(0), 1-37. https://doi.org/10.1080/09588221.2020.1799821

Fransiska, R. and J. (2016). The Use of Drilling Technique in Teaching English Vocabulary to the 
Seventh Grade Students of SMP Negeri 2 Tanggulangin. Anglicist, 05(02), 125-131.

Kuo, Y. C., \& Kuo, Y. T. (2020). Preservice teachers' mobile learning experience: An exploratory study of iPad-enhanced collaborative learning. Journal of Digital Learning in Teacher Education, 36(2), 111-123. https://doi.org/10.1080/21532974.2020.1719380

Maharani, R., Marsigit, M., \& Wijaya, A. (2020). Collaborative learning with scientific approach and multiple intelligence: Its impact toward math learning achievement. Journal of Educational Research $113(4)$ 303-316. https://doi.org/10.1080/00220671.2020.1806196

Manegre, M., Gutiérrez-colón, M., \& Manegre, M. (2020). Foreign language learning through collaborative writing in knowledge building forums knowledge building forums. Interactive Learning Environments, $\quad 0(0), \quad 1-13$. https://doi.org/10.1080/10494820.2020.1836499

Mbirimi-Hungwe, V., \& McCabe, R. M. (2020). Translanguaging during collaborative learning: A 'transcollab' model of teaching. Southern African Linguistics and Applied Language Studies, 38(3), 244-259. https://doi.org/10.2989/16073614.2020.1847670

$\mathrm{Su}, \mathrm{F} ., \quad \&$ Zou, D. (2020). Technology-enhanced collaborative language learning: theoretical foundations, technologies, and implications. Computer Assisted Language Learning, O(0), 135. https://doi.org/10.1080/09588221.2020.1831545

Troussas, C., Giannakas, F., Sgouropoulou, C., Giannakas, F., \& Sgouropoulou, C. (2020). Collaborative activities recommendation based on students ' collaborative learning styles using ANN and WSM collaborative learning styles using ANN and WSM. Interactive Learning Environments, O(0), 1-14. https://doi.org/10.1080/10494820.2020.1761835

Vahed, A., \& Rodriguez, K. (2020). Enriching students' engaged learning experiences through the collaborative online international learning project. Innovations in Education and Teaching International, 00(00), 1-10. https://doi.org/10.1080/14703297.2020.1792331 